\title{
PENINGKATAN PERILAKU TERPUJI SISWA MELALUI PENERAPAN HUKUMAN DAN POLA ASUH ORANG TUA SISWA
}

\author{
MUHAMAD JAMI RUSMAN \\ Sekolah Dasar Negeri Karang Tengah 9 Kota Tangerang \\ Jamirusman1883@gmail.com
}

\begin{abstract}
ABSTRAK
Perilaku terjadi melalui proses adanya interaksi antara individu dengan lingkungannya sebagai keadaan jiwa untuk berpendapat, berpikir, dan bersikap yang merupakan gerakan dari berbagai aspek baik fisik maupun non fisik. Berperilaku yang baik bagi anak merupakan suatu hal yang paling penting yang wajib diberikan keluarga terutama orang tua dalam mengasuh anak, bila anak mempunyai perilaku yang baik akan membawa anak menuju rasa tentram dikemudian hari. Pola asuh orang tua mempunyai peranan yang sangat penting bagi perkembangan perilaku moral pada anak, karena dasar perilaku moral pertama diperoleh oleh anak dari dalam rumah yaitu orang tuanya. Menururt Baumrind ada empat macam bentuk pola asuh orang tua yang diterapkan oleh masing-masing orang tua, bentuk-bentuk pola asuh itu adalah: pola asuh otoriter, pola asuh demokrasi, pola asuh penelantaran dan pola asuh permisif. Perbedaan pola asuh orang tua seperti ini dapat berpengaruh terhadap perbedaan perkembangan emosi remaja, sebagai contoh cara memberi hukuman misalnya, kalau dulu anak dipukul karena nakal, pada masa remaja cara semacam itu justru dapat menimbulkan ketegangan yang lebih berat antara remaja dengan orang tuanya. Hukuman merupakan salah alat pendidikan represif. Alat ini memang bukan merupakan alat yang menjadi alternatif pertama dalam mendidik anak, karena sebelum menggunakan alat pendidikan ini harus terlebih dahulu menggunakan alat lain seperti nasihat dan teladan.
\end{abstract}

Kata Kunci: Perilaku Terpuji Siswa dan Penerapan Hukuman

\begin{abstract}
Behavior occurs through the process of interaction between the individual and his environment as a state of mind to think, think, and behave which is a movement from various aspects both physical and non-physical. Good behavior for children is the most important thing that must be given by the family, especially parents in caring for children, if the child has good behavior will bring the child to feel at ease in the future. Parenting parents have a very important role for the development of moral behavior in children, because the basic moral behavior is first obtained by the child from home, namely his parents. According to Baumrind, there are four types of parenting practices applied by each parent, the forms of parenting are: authoritarian parenting, democratic parenting, neglect parenting and permissive parenting. Differences in parenting parents like this can affect differences in adolescent emotional development, for example how to give punishment for example, if the child was beaten for being naughty in the past, during adolescence such a method can actually cause more severe tension between adolescents and their parents. Punishment is a repressive educational tool. This tool is indeed not the first alternative tool in educating children, because before using this educational tool must first use other tools such as advice and example.
\end{abstract}

Keywords: Student Praiseworthy Behavior and Application of Punishment 


\section{A. PENDAHULUAN}

Pendidikan adalah suatu proses yang dilakukan secara sadar, terus menerus, terarah dan berkesinambungan untuk mencapai suatu tujuan tertentu, tujuan pendidikan merupakan faktor utama yang harus diperhatikan, disadari dan dijadikan sasaran oleh setiap pendidik yang melaksanakan kegiatan pendidikan. Pendidikan merupakan sarana yang dibutuhkan untuk pengembangan kehidupan manusia. Maka dari itu pendidikan senantiasa menjadi perhatian utama dalam rangka memajukan kehidupan generasi yang sejalan dengan tuntutan kemajuan mayarakat dan bangsanya. Pendidikan mempunyai banyak arti. Emile Durkheim mendefinisikan pendidikan sebagai pengaruh yang dilaksanakan oleh orang dewasa atas generasi yang belum matang untuk penghidupan sosial. ${ }^{1}$

Pendidikan sebagai suatu pembentukan watak/kepribadian, juga harus dapat mempersiapkan sumber daya yang handal, terutama dalam memasuki abad ke-21, yang merupakan era persaingan bebas (globalisasi) yang menuntut ketersediaan sumber daya manusia yang berkualitas dan mampu bersaing dalam tatanan global. Sejalan dengan hal tersebut maka menurut Undang-Undang Nomor 20 Tahun 2003 tentang Sistem Pendidikan Nasional pada bab II pasal 3 menyebutkan bahwa: Pendidikan Nasional berfungsi mengembangkan kemampuan dan membentuk watak serta peradaban bangsa yang bermartabat dalam rangka mencerdaskan kehidupan bangsa, tujuan untuk berkembangnya peserta didik agar menjadi manusia yang beriman, bertakwa kepada Tuhan Yang Maha Esa, berakhlak mulia, sehat, berilmu, cakap, kreatif, mandiri dan menjadi warga Negara yang demokratis serta bertanggung jawab. ${ }^{2}$

Pendidikan Nasional yang berdasarkan atas Pancasila dan bertujuan untuk meningkatkan ketakwaan terhadap Tuhan Yang Maha Esa, kecerdasan, keterampilan, mempertinggi budi pekerti, memperkuat kepribadian dan mempertebal semangat kebangsaan agar menumbuhkan manusia-manusia pembangunan yang membangun dirinya sendiri serta bersama-sama bertanggung jawab atas pembangunan bangsa. Peranan pendidikan sangatlah penting sebagai usaha membangun manusia yang berkualitas yang dilandasi dengan peningkatan kecerdasan, pengetahuan, sikap dan keterampilan. Proses pendidikan diawali ketika individu dilahirkan dilanjutkan dengan Penerapan Pola Asuh Orang Tua dalam lingkungan keluarga kemudian dilanjutkan dan dikembangkan melalui jenjang pendidikan formal, terstruktur dan sistematis dalam lingkungan sekolah. Pola Asuh Orang Tua adalah kemampuan dan kesiapan orang tua memberi contoh serta membantu, mendidik, mengawasi dan memimpin anak agar anak dapat berdiri sendiri dan juga orang tua dapat memperbaiki kehidupan anak yang kurang baik sehingga menjadi baik. Pola

${ }^{1}$ Emile Durkheim, Pendidikan Moral: Suatu Studi teori dan aplikasi sosiologi pendidikan, terjemah oleh Lukas Ginting (Jakarta: Erlangga, 1990), 2-3

${ }_{2}^{2}$ Undang-undang Sisdiknas Sistem Pendidikan Nasional (Jakarta: Sinar Grafika, 2003), 5-6. 
asuh orang tua dengan anak berdisiplin diri dimaksudkan sebagai upaya orang tua dalam meletakan dasar-dasar disiplin kepada anak dan membantu pengembangannya sehingga anak memiliki disiplin diri. ${ }^{3}$ Pola Asuh Orang Tua mempunyai peranan yang sangat penting bagi perkembangan perilaku moral pada anak, karena dasar perilaku moral pertama diperoleh oleh anak dari dalam rumah yaitu Pola Asuh Orang Tuanya. Proses pengembangan melalui pendidikan disekolah tinggal hanya melanjutkan perkembangan yang sudah ada.

Menurut Chatib Thoha yang mengemukakan bahwa Pola Asuh Orang Tua adalah suatu cara terbaik yang dapat ditempuh orang tua dalam mendidik anak sebagai perwujudan dari rasa tanggung jawab kepada anak. ${ }^{4}$ Setiap orang tua berkewajiban untuk mengasuh dan mendidik anaknya, sebagai contoh, bagaimana sikap atau perilaku orang tua dalam menerapkan aturan, mengajarkan nilai/norma, mem-berikan perhatian dan kasih sayang serta menunjukan sikap dan perilaku yang baik sehingga dijadikan contoh/model bagi anaknya. Casmini menyatakan bahwa gaya pengasuhan orang tua meliputi authorian, authoritative, dan permissive yang didalamnya terdapat praktek-praktek pengasuhan yang mendeskripsikan bagaimana orang tua memberikan dan meperlakukan anak yang terdiri dari peraturan, hukuman, hadiah, kontrol dan komunikasi. Pengasuhan authoritarian merupakan pengasuhan dimana orang tua suka memaksa anak-anaknya untuk patuh terhadap aturan-aturan, berusaha membentuk tingkah laku serta cenderung mengekang keinginan anak. Orang tua tidak mendorong untuk mandiri, jarang memberi pujian, hak anak sangat dibatasi tetapi dituntut mempunyai tanggung jawab sebagimana halnya orang dewasa. Anak harus tunduk dan patuh pada orang tua. Pengontrolan tingkah laku anak sangat ketat, sering menghukum anak dengan hukuman fisik, serta orang tua terlalu banyak mengatur kehidupan anak.

Pengasuhan authoritative adalah pengasuhan dimana orang tua selalu memberikan alasan kepada anak saat bertindak, mendorong untuk saling membantu dan bertindak secara objektif. Orang tua cenderung tegas tetapi hangat dan penuh perhatian sehingga anak tampak ramah, kreatif dan percaya diri, mandiri dan bahagia serta memiliki rasa tanggung jawab sosial. Orang tua bersikap bebas atau longgar namun masih dalam batas-batas normatif. Pengasuhan permissive memberikan kebebasan kepada anak seluas mungkin dan sangat longgar. Anak mendapat kebebasan mengatur dirinya sendiri. Tidak ada tuntutan bagi anak untuk belajar bertanggung jawab. ${ }^{5}$

Dalam lingkungan keluarga orang tua sebagai pendidik di dalam keluarga memegang peranan yang sangat esensial dan strategis karena semua

${ }^{3}$ Schohib, Pola Asuh Orang Tua Dalam Membantu Anak Mengembangkan Disiplin Diri (Jakarta: Rineka Cipta, 2001), 16.

${ }^{4}$ Chaotib Thoha, Kapita Selekta Pendidikan Islam (Yogyakarta: Pustaka Pelajar, 2003), 109.

${ }^{5}$ Casmini, Emotional Parenting Dasar-dasar Pengasuhan Kecerdasan Emosi Anak (Yogyakarta: Pilar Media, 2007), 7. 
perilaku orang tua dalam pola asuhannya akan dijadikan model anak-anaknya dan pada gilirannya anak dalam mengidentifikasi segala sesuatunya. Sedangkan strategis dimaksudkan karena kepemimpinannya orang tua yang diterima oleh anak akan berdampak secara berarti bagi perkembangan psikologis anak. Orang tua menjadi pendidik pertama dan utama bagi pendidikan anak terutama dalam penanaman keimanan, dan keimanan tersebut sangat diperlukan oleh anak sebagai landasan bagi akhlak mulia. ${ }^{6}$

Dalam upaya pencapaian tujuan pendidikan, salah satu hal yang diperlukan adalah alat pendidikan. Dalam proses pendidikan, alat pendidikan mempunyai kedudukan yang sangat penting, karena tanpa alat pendidikan seperti: bangunan sekolah, papan tulis, buku, tata tertib, hukuman dan sebagainya, maka sudah bisa dipastikan proses belajar mengajar di sekolah akan terganggu karena kurangnya fasilitas yang mendukung. Hukuman dapat diartikan sebagai penderitaan yang diberikan atau ditimbulkan dengan sengaja oleh seseorang (orang tua, guru, dan sebagainya) sesudah terjadi suatu pelanggaran, kejahatan atau kesalahan, atau dengan kata lain suatu perbuatan yang tidak menyenangkan dari orang yang lebih tinggi kedudukannya untuk pelanggaran dan kejahatan, dengan maksud memperbaiki kesalahan anak, bukan untuk mendendam. ${ }^{7}$ Dengan demikian, pemberlakuan hukuman dalam mendidik anak tidak terhenti pada hukuman itu sendiri, melainkan pada tujuan yang ada dibelakangnya, yaitu agar manusia yang melanggar itu insyaf, bertaubat, dan kembali menjadi orang yang berperilaku lebih baik.

Dengan adanya sanksi atau hukuman diharapkan anak akan lebih patuh terhadap suatu peraturan, dan anak akan merasa takut untuk me-lakukan pelanggaran dan sebagainya. ${ }^{8}$ Penerapan sanksi dan hukuman tersebut, menurut S. Nasution merupakan salah satu tujuan pendidikan, yaitu melakukan perubahan kelakuan dan sikap anak didik seperti yang diharapkan masyarakat. ${ }^{9}$ Selanjutnya hukuman adalah tindakkan yang dijatuhkan kepada anak secara sadar dan sengaja sehingga menimbulkan nestapa. Dan dengan adanya nestapa itu anak menjadi sadar akan perbuatannya dan berjanji dalam hatinya untuk tidak mengulanginya. ${ }^{10}$ Hukuman biasa dikenal dengan nama Azab, kata Azab didalam Al-Qur'an diulang sebanyak 373 kali. Jumlah yang banyak ini menunjukan perhatian Al-Qur'an yang amat besar terhadap masalah hukuman ini, dan meminta perhatian umat manusia. Selanjutnya didalam Al-Qur'an mengenai hukuman, misalnya dapat dijumpai dalam surat An-Nur ayat 2:

${ }^{6}$ Ahmad Tafsir, Pendidikan Anak dalam Keluarga (Bandung: Remaja Rosdakarya, 1996), 8.

7 J.S. Badudu dan Sutan Muhammad Zain, Kamus Umum Bahasa Indonesia (Jakarta: Pustaka Sinar Harapan, 1996), 520.

${ }^{8}$ Slameto, Belajar dan Faktor-Faktor yang Mempengaruhinya (Jakarta: Rineka Cipta, 1996), 37.

${ }^{9}$ S. Nasution, Sosiologi Pendidikan (Jakarta: Bumi Aksara, 1995), 10.

${ }_{10}$ Amin Daten Indra Kusuma, Pengantar Ilmu Pendidikan (Surabaya: Usaha Nasiaonal, 1999), 147. 


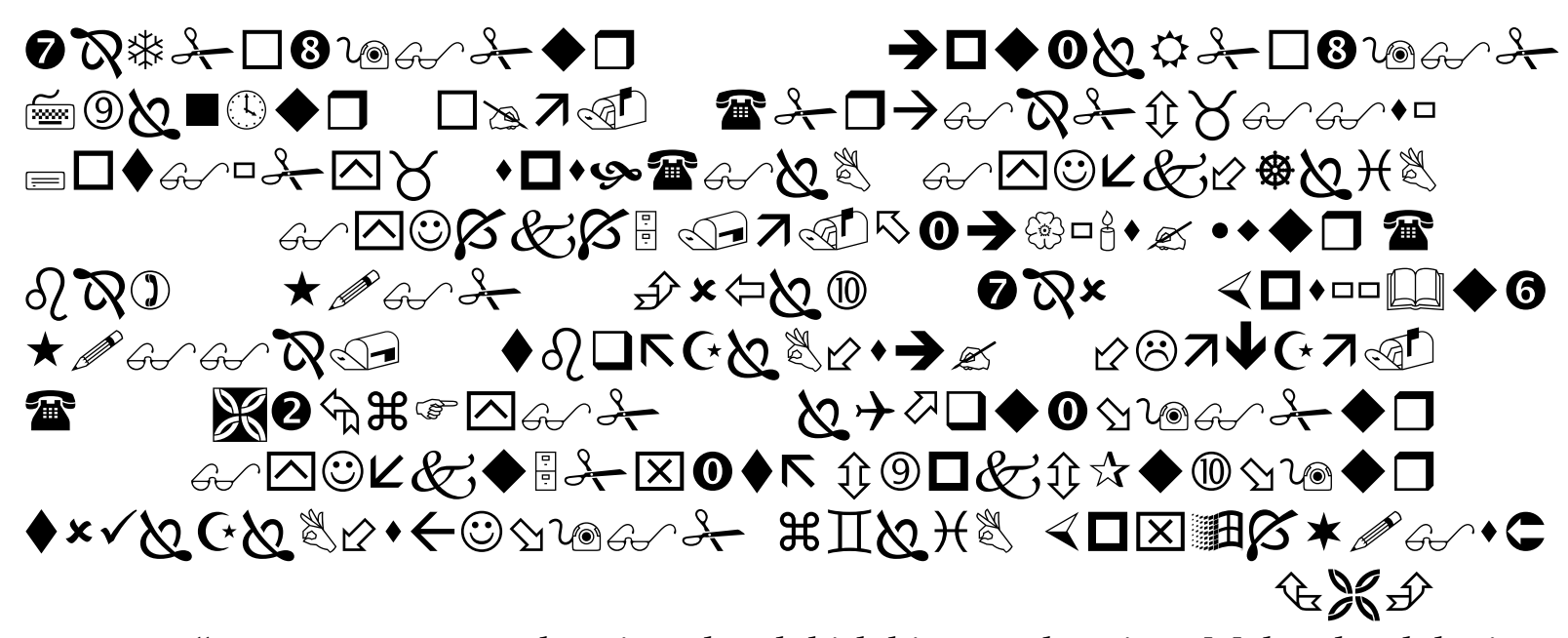

“perempuan yang berzina dan laki-laki yang berzina, Maka deralah tiaptiap seorang dari keduanya seratus dali dera, dan janganlah belas kasihan kepada keduanya mencegah kamu untuk (menjalankan) agama Allah, jika kamu beriman kepada Allah, dan hari akhirat, dan hendaklah (pelaksanaan) hukuman mereka disaksikan oleh sekumpulan orang-orang yang beriman."

Ayat ini memberikan penjelasan tentang pemberian hukuman kepada laki-laki dan perempuan yang melakukan perzinahan, dengan cara didera atau dicambuk sebanyak seratus kali cambukkan dan jangan berbelas kasihan terhadap orang yang melakukan perzinahan.

Hukuman merupakan produk dari sistem otoriter. Pemberian hukuman tidak mendidik anak-anaknya untuk bersikap percaya diri, disiplin pribadi, dan kesadaran terhadap diri sendiri juga tidak mendorong keberanian anak untuk ikut berperan atau bersikap kreatif, karena dengan hukuman, orang tua menekan daya kreativitas anak yang sedang berkembang. Anak tidak akan berani mencoba, dan ia tidak akan mengembangkan kemampuan untuk melakukan sesuatu karena tidak mendapatkan kesempatan mencoba. Juga anak akan kehilangan spontanitas, dan tidak dapat mencetuskan ide-ide baru. Ia merasa tidak dapat mengimbangi teman-temannya dalam segala hal, sehingga anak menjadi pasif dalam bergaul. Lama kelamaan ia aka mempunyai perasaan rendah diri dan akan kehilangan kepercayaan kepada diri sendiri.

Jika seorang anak mendapat hukuman di sekolah, dan ia tidak bisa menerima hukuman tersebut dengan nyaman, maka hal tersebut akan berdampak buruk terhadap kecintaan dia kepada sekolah, teman dan para guru. Dan itu akan mendorong anak untuk mengakhiri (memutus) hubungan positif dengan orang-orang tersebut. Selanjut-nya, akan tumbuh dalam jiwa akan berhubungan yang buruk dengan mereka, yaitu perasaan merasa kurang dapat kasih sayang dan merasa "terpencil" secara sosial. Dan jika hal ini terjadi, semuanya itu akan mendorong mereka untuk menjalin pergaulan dengan teman-temannya yang tidak baik yang bernasib sama kemudian mereka akan membuat aliansi itu dengan cara saling mencintai dan saling membuka rahasia diantara mereka. Penerapan hukuman juga diterapkan Pada lembaga pendidikan MAN 10 joglo Jakarta Barat, aturan yang diterapkan oleh pihak 
sekolah antara lain adalah mewajibkan bagi setiap siswi dan siswa untuk memasukkan baju seragam mereka ke dalam rok atau celana dan wajib pula memakai dasi bagi siswa atau siswi, hukuman bagi mereka yang melanggar biasanya langsung ditegur di tempat dan langsung memerintahkan mereka untuk merapikan pakaian mereka.

Lain daripada itu sekolah juga maih banyak dihadapkan dengan beberapa perilaku siswa yang masih sering membolos sekolah, menyontek saat ulangan, merokok dan lain sebagainya. Oleh karena itu, lingkungan keluarga atau orang tua dirumah mempunyai andil juga dalam memperbaiki karakter mereka. Gejala-gejala yang diperlihatkan oleh siswa-siswa tersebut dapat disebabkan oleh berbagai faktor, yaitu faktor-faktor yang berasal dari dalam diri siswa dan faktor-faktor yang berasal dari luar dirinya. Kedua faktor itu dapat berpengaruh terhadap perilaku siswa.

Dengan latar belakang yang telah disebutkan di atas, maka peneliti tertarik untuk meneliti bagaimana Penerapan Hukuman dalam merubah perilaku siswa menjadi lebih baik atau minimal siswa tidak melanggar peraturan yang telah dibuat oleh pihak sekolah, dan apakah sejauh ini siswa menganggap Penerapan Hukuman sangat berpengaruh dengan Perilaku Siswa atau malah sebaliknya dan penelitian ini juga akan meneliti bagaimana Orang Tua Siswa dalam menerapkan Pola Asuh. Maka dari itu peneliti tertarik untuk meneliti tentang Pengaruh Penerapan Hukuman dan Pola Asuh Orang Tua terhadap Perilaku Siswa Madarsah Aliyah Negeri 10 Jakarta.

\section{B. METODE PENELITIAN}

Metode penelitian dapat diartikan dalam arti yang luas sebagai cara ilmiah, pada penelitian bisa dilakukan dengan menggunakan berbagai macam metode. Pada penelitian ini penulis menggunakan metode survai dengan pendekatan korelasional. Metode Penelitian dalam pengertian yang luas dapat diartikan sebagai cara ilmiah, untuk mendapatkan data dengan tujuan dan kegunaan tertentu. Sugiyono ${ }^{11}$ mengemukakan bahwa ada empat kata kunci yang perlu diperhatikan dalam menjelaskan metode penelitian, yaitu: cara ilmiah yang berarti kegiatan penelitian itu dilakukan berdasarkan pada karakteristik keilmuan, yakni rasional, emparis dan sistematis. Rasional yang berarti kegiatan penelitian itu dilakukan dengan cara-cara yang masuk akal, sehingga terjangkau oleh penalaran manusia. Empiris, yakni cara-caraa yang dilakukan dalam penelitian dapat diamati oleh indera manusia, sehingga orang lain dapat mengamati dan mengetahui cara-cara yang digunakan. Sistematis, artinya proses yang digunakan dalam penelitian ini menggunakan langkah-langkah tertentu yang bersifat logis. Walaupun langkah-langkah penelitian antara metode kuantitatif, kualitatif dan Research and Developement (RED) berbeda, akan tetapi seluruhnya sistematis.

\footnotetext{
${ }^{11}$ Sugiyono, Metode Penelitian Pendidikan Pendekatan Kuantitatif, Kualitatif, dan R \& D, 117.
} 
Metode survai dipergunakan dengan pertimbangan-pertimbangan bahwa penelitian dilakukan untuk mendapatkan data setiap variabel masalah penelitian dari tempat tertentu yang alamiah (bukan buatan) dengan alat pengumpul data berbentuk angket (kuesioner), test dan wawancara terstruktur dan berdasarkan pandangan dari sumber data, bukan dari peneliti. Populasi adalah keseluruhan subjek penelitian. Apabila seseorang ingin meneliti semua elemen yang ada dalam wilayah penelitian, maka penelitiannya merupakan penelitian populasi. Studi atau penelitiannya juga disebut studi populasi atau studi sensus..$^{12}$ Adapun populasi target dalam penelitian ini adalah seluruh siswa kelas XI MAN 10 Jakarta.

\section{HASIL DAN PEMBAHASAN}

Berdasarkan hasil pengujian hipotesis sebagaimana telah diuraikan, maka secara keseluruhan temuan dalam penelitian ini, dapat dibahas dengan cara mengkonfirmasi terhadap teori-teori yang sudah ada, sebagaimana telah dikemukakan pada Bab II, jadi dalam pembahasan penelitian ini akan diuraikan hasil temuan penelitian dan menguraikan hasil uji hipotesis beserta teori-teori yang telah diungkapkan sebelumnya.

Dari hasil analisis deskriptif variabel penelitian variabel Perilaku Siswa dilihat dari skor rata-rata Perilaku Siswa yaitu 138,83 atau sama dengan $138,83: 150 \times 100 \%=92.55 \%$ dari skor idealnya yaitu 150. Data ini dapat ditafsirkan sebagai tingkat atau taraf perkembangan variabel tersebut dengan kriteria sebagai berikut. Pada kriteria taraf sangat tinggi sebesar 92,55\%, hal ini menunjukkan bahwa pentingnya meningkatkan perilaku terpuji siswa baik dilingkungan sekolah, keluarga, dan masyarakat. Untuk variabel Penerapan Hukuman di lihat dari skor rata-rata yaitu 141,53 atau sama dengan 141,53:150 X $100 \%=94,35 \%$ dari skor idealnya yaitu 150, pada kriteria taraf sangat tinggi sebesar 94,35\%. Hal ini menunjukkan bahwa pentingnya Penerapan Hukuman baik di lingkungan sekolah atau lingkungan keluarga. Sedangkan variabel Pola Asuh Orang Tua dilihat dari skor rata-rata Pola Asuh Orang Tua yaitu 139,34 atau sama dengan $139,34: 150 \times 100 \%=92,89 \%$ dari skor idealnya yaitu 150 , pada kriteria taraf sangat tinggi sebesar 92,89\%, hal ini menunjukkan bahwa Pola Asuh Orang Tua yang sesuai dengan tuntunan agama dapat mempengaruhi akan perilaku anak.

Sedangkan pada hasil uji persyaratan hipotesis penelitian telah terpenuhi, yakni uji linieritas persamaan regresi $\hat{Y}$ atas $X_{1}$ dengan hasil $P$ Sig $=0,315>0,05$ $(5 \%)$ atau Fhitung $=1,113$ dan $\mathrm{F}_{\text {tabel }}$ dengan dk pembilang $46 \mathrm{dan} \mathrm{dk}$ penyebut 69 dan pada taraf kepercayaan (signifikansi) $\alpha=0,05$ adalah 1.69 (Fhitung $\left.1,113<\mathrm{F}_{\text {tabel }} 1,62\right)$ berarti $\hat{Y}$ atas $\mathrm{X}_{1}$ adalah linear dan persamaan regresi $\mathrm{Y}$ atas $\mathrm{X}_{2}$ menunjukkan nilai P Sig $=0,140>0,05(5 \%)$ atau Fhitung $=0,426$ dan $F_{\text {tabel }}$ dengan

${ }_{12}$ Suharsimi Arikunto, Prosedur Penelitian Suatu Pendekatan Praktek (Jakarta: Rineka Cipta, 2002), 108. 
dk pembilang 20 dan dk penyebut 95 dan pada taraf kepercayaan (signifikansi) $\alpha=0,05$ adalah 1,65 (Fhitung $0,426<\mathrm{F}_{\text {tabel }} 1,67$ ) yang berarti $\hat{Y}$ atas $\mathrm{X}_{2}$ adalah linear. Sedangkan untuk uji normalitas persamaan regresi $\hat{Y}$ atas $X_{1}$ dan $X_{2}$ menunjukkan Asymp. Sig (2-tailed) atau nilai $\mathrm{P}=0,200>0,05$ (5\%) atau $Z$ hitung 0.070 dan $Z_{\text {tabel }}$ pada taraf kepercayaan/signifikansi $\alpha=0,05$ adalah 1,645 (Zhitung 0.070

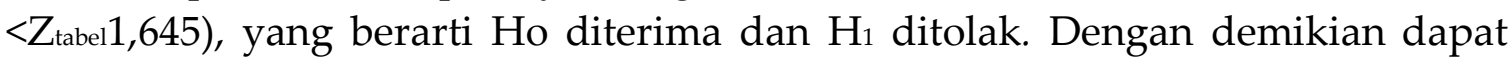
diinterpretasikan atau ditafsirkan bahwa persyaratan normalitas distribusi galat taksiran terpenuhi dengan kata lain galat taksiran persamaan regresi $\hat{Y}$ atas $X_{1}$ dan $\mathrm{X}_{2}$ adalah berdistribusi normal.

Untuk selanjutnya akan menguraikan hasil uji hipotesis beserta teori-teori yang telah diungkapkan sebelumnya.

Pertama, hasil penelitian ini sejalan dengan teori Penerapan Hukuman yang dikemukakan oleh Ngalim Purwanto mendefinisikan hukuman sebagai "penderitaan yang diberikan atau ditimbulkan dengan sengaja oleh seseorang (orang tua, guru, dan sebagainya) sesudah terjadi suatu pelanggaran, kejahatan atau kesalahan." Dalam pengertian di atas Ngalim Purwanto mengatakan bahwa penderitaan itu diberikan secara sengaja, hal ini dikarenakan ada pula penderitaan yang tidak disengaja seperti orang atau anak tersayat jarinya ketika bermain dengan pisau.

Hukuman yang demikian disebut dengan hukuman alam, selain itu menurut Ngalim, ia menggariskan bahwa sebagai salah satu alat pendidikan hukuman yang diberikan kepada siswa hendaklah senantiasa merupakan jawaban atas suatu pelanggaran, selain itu sedikit banyaknya hukuman juga hendaknya selalu bersifat tidak menyenangkan dan selalu bertujuan kearah perbaikan.

Dengan adanya sanksi atau hukuman siswa akan lebih patuh terhadap suatu peraturan, dan siswa akan merasa takut untuk melakukan pelanggaran dan sebagainya. ${ }^{13}$ Penerapan sanksi dan hukuman tersebut, menurut S. Nasution merupakan salah satu tujuan pendidikan, yaitu melakukan perubahan kelakuan dan sikap anak didik seperti yang diharapkan masyarakat. ${ }^{14}$ Selanjutnya hukuman adalah tindakkan yang dijatuhkan kepada anak secara sadar dan sengaja sehingga menimbulkan nestapa. Dan dengan adanya nestapa itu anak menjadi sadar akan perbuatannya dan berjanji dalam hatinya untuk tidak mengulanginya. ${ }^{15}$

Hukuman biasa dikenal dengan nama Azab, kata azab didalam Al-Qur'an diulang sebanyak 373 kali. Jumlah yang banyak ini menunjukan perhatian AlQur'an yang amat besar terhadap masalah hukuman ini, dan meminta perhatian umat manusia. Selanjutnya didalam Al-Qur'an mengenai hukuman, misalnya dapat dijumpai dalam surat An-Nur ayat 2:

${ }^{13}$ Slameto, Belajar dan Faktor-Faktor yang Mempengaruhinya (Jakarta: Rineka Cipta, 1996), 37.

14 S. Nasution, Sosiologi Pendidikan (Jakarta: Bumi Aksara, 1995), 10.

${ }^{15}$ Amin Daten Indra Kusuma, Pengantar Ilmu Pendidikan (Surabaya: Usaha Nasiaonal, 1999), 147. 


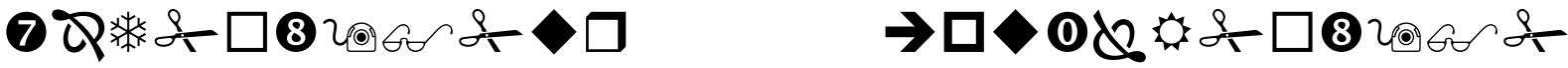

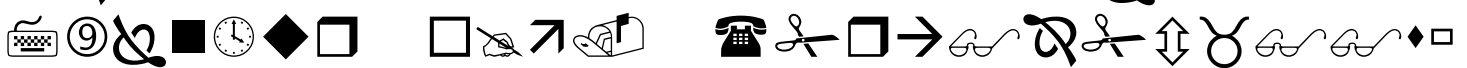

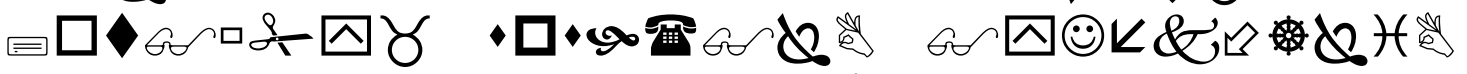

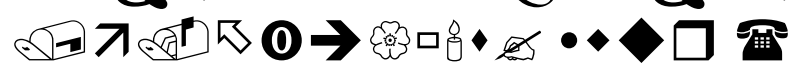

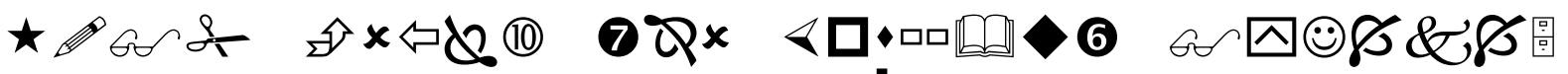

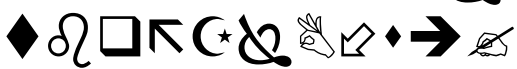

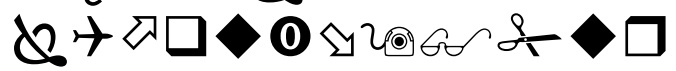 $\checkmark \otimes \pi \downarrow C \lambda$ वरे(ग) * ar Go QR日 令 (9)

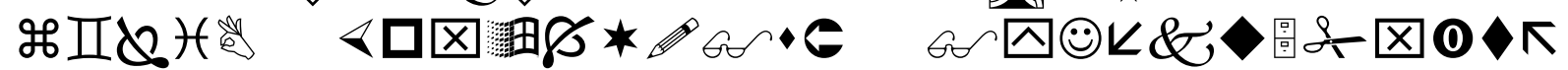

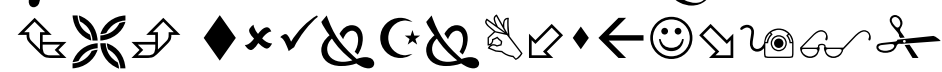

\begin{abstract}
“perempuan yang berzina dan laki-laki yang berzina, Maka deralah tiaptiap seorang dari keduanya seratus dali dera, dan janganlah belas kasihan kepada keduanya mencegah kamu untuk (menjalankan) agama Allah, jika kamu beriman kepada Allah, dan hari akhirat, dan hendaklah (pelaksanaan) hukuman mereka disaksikan oleh sekumpulan orang-orang yang beriman."
\end{abstract}

Ayat ini memberikan penjelasan tentang pemberian hukuman kepada laki-laki dan perempuan yang melakukan perzinahan, dengan cara didera atau dicambuk sebanyak seratus kali cambukkan dan jangan berbelas kasihan terhadap orang yang melakukan perzinahan.

Lalu diayat lain Allah SWT menjelaskan tentang pemberian hukuman kepada laki-laki dan perempuan yang mencuri, potonglah olehmu kedua tangannya, sebagai balasan atas apa yang mereka kerjakan seperti yang terdapat dalam Al-Qur'an surat Al-Maidah ayat 38:

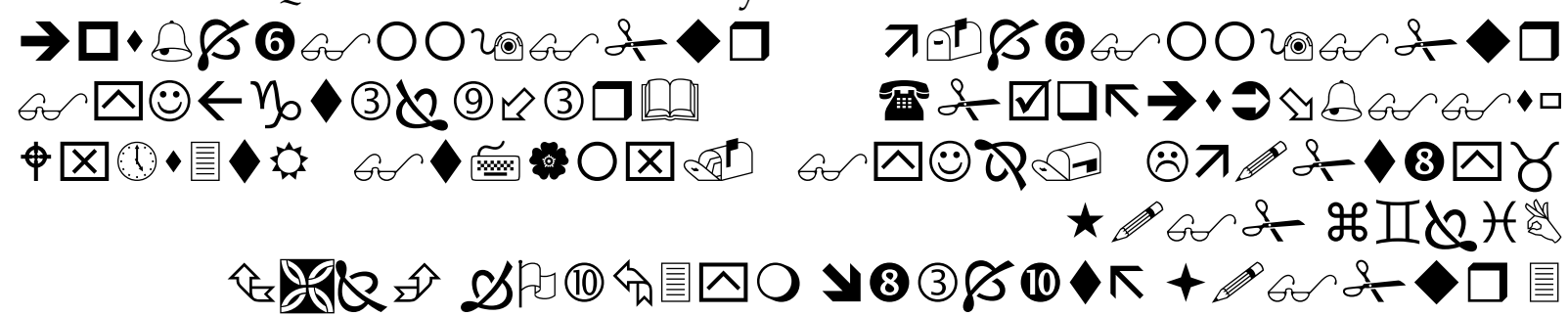

"laki-laki yang mencuri dan perempuan yang mencuri, potonglah tangan keduanya (sebagai) pembalasan bagi apa yang mereka kerjakan dan sebagai siksaan dari Allah. dan Allah Maha Perkasa lagi Maha Bijaksana."

Ayat-ayat tersebut diatas selain mengakui keberadaan hukuman dalam rangka perbaikan umat manusia, juga menunjukan bahwa hukuman itu tidak diberlakukan kepada semua manusia, melainkan khusus kepada manusiamanusia yang melakukan pelangaran saja. Manusia yang model seperti itu biasanya sulit diperbaiki hanya dengan nasehat atau teladan saja, melainkan harus lebih berat lagi, yaitu dengan diberikan hukuman fisik.

Adanya hukuman seperti itu tidak dapat dikatakan sebagai tidak manusiawi, karena pengertian manusiawi juga termasuk manusia dengan segala 
kekurangannya. Membiarkan manusia yang melanggar dan membiarkan mereka berkeliaran dan meresahkan masyarakat adalah sangat tidak manusiawi, karena akan membawa kehancuran kepada lingkungan masyarakat. Dengan demikian, pemberlakuan hukuman dalam pendidikan tidak terhenti pada hukuman itu sendiri, melainkan pada tujuan yang ada dibelakangnya, yaitu agar manusia yang melanggar itu insyaf, bertaubat, dan kembali menjadi orang yang lebih baik.

Kedua, hasil penelitian ini mendukung teori Pola Asuh Orang Tua sebagaimana dikemukakan Sugihartono dkk, mengatakan bahwa pola asuh adalah Pola perilaku yang diterapkan pada anak dan bersifat konsisten dari waktu ke waktu. Pola asuh yang diterapkan tiap keluarga berbeda dengan keluarga lainnya. Pola perilaku ini dapat dirasakan oleh anak, dari segi negatif dan positif. Pola asuh juga dapat memberi perlindungan, dan mendidik anak dalam kehidupan sehari-hari.

Pola asuh dapat berarti menjadi orang tua (Parenting) atau pola pengasuhan (rearing). Menurut Erikson (dalam Bigner) alasan orang tua menjadi orang tua ialah adanya perasaan berhasil (sense of generativity) yang muncul ketika seseorang mencapai kedewasaan dengan berbagai rangsangan fisik, psikologi, dan sosial. ${ }^{16}$ Interaksi yang pertama kali terjadi dalam kehidupan seorang anak adalah dengan keluarga. Dengan demikian, nyatalah bahwa keluarga khususnya orang tua memiliki peran yang sangat penting dalam proses berkembangnya perilaku anak menuju kedewasaan fisik dan psikis.

Adapun yang menjadi dasar pengasuhan orang tua didalam al-Qur'an terdapat didalam beberapa surah dalam al-Qur'an diantaranya:

a. Al-Qur'an surat Thaha/20:132

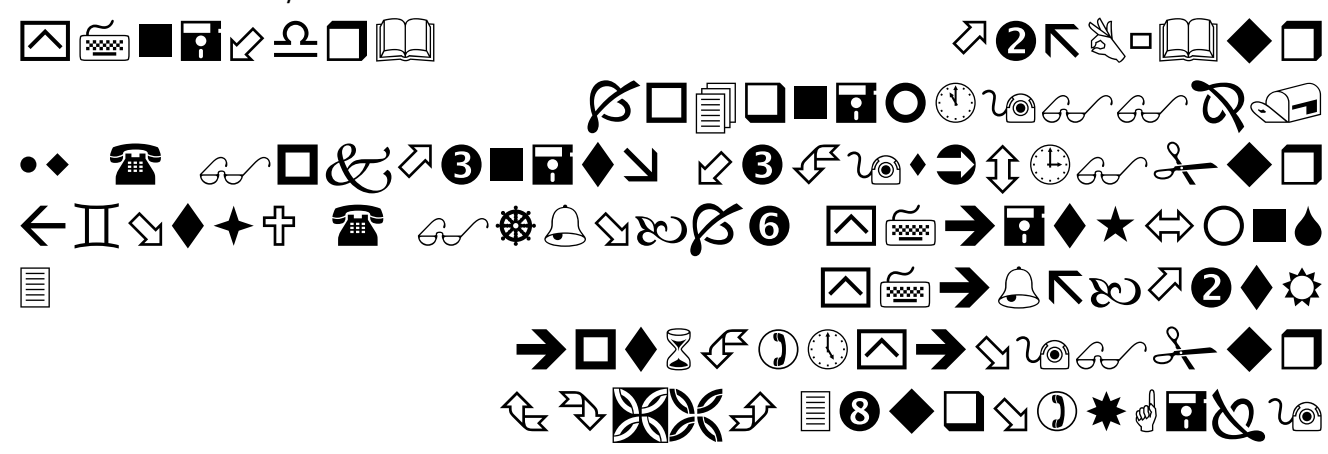

"dan perintahkanlah kepada keluargamu mendirikan shalat dan bersabarlah kamu dalam mengerjakannya. Kami tidak meminta rezki kepadamu, kamilah yang memberi rezki kepadamu. dan akibat (yang baik) itu adalah bagi orang yang bertakwa."

b. Terdapat juga didalam al-Qur'an surat Luqman/31:14:

16 J.B, Bigner, Parent Child Relation An Introduction To Parenting (New York Mac Millan Publishing Co, Mac Millan Publishing, 1779), 86. 


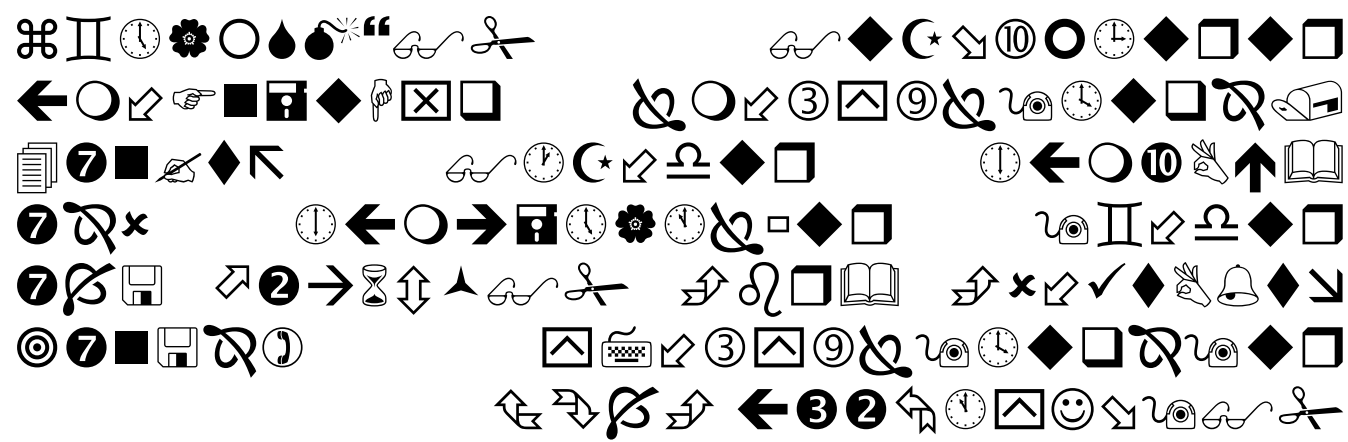

"dan Kami perintahkan kepada manusia (berbuat baik) kepada dua orang ibu-bapanya; ibunya telah mengandungnya dalam Keadaan lemah yang bertambah-tambah, dan menyapihnya dalam dua tahun. bersyukurlah kepadaku dan kepada dua orang ibu bapakmu, hanya kepada-Kulah kembalimu."

Dari beberapa ayat tersebut diatas menjelaskan bahwa Allah memerintahkan bagi orang-orang beriman untuk saling menjaga keluarga dari api neraka. Orang tua dan anak mempunyai kewajiban dan tugasnya masingmasing, orang tua bertugas untuk mendidik, membimbing dan mengajarkan anak-anaknya kepada kebaikan dan berperilaku sesuai dengan perintah agama serta memerintahkan anak untuk selalu mendirikan sholat, begitupun kewajiban anak kepada orang tua harus berbakti dan berbuat baik kepada kedua orang tua.

\section{KESIMPULAN}

Berdasarkan hasil penelitian pada jurnal ini dapat disimpulkan bahwa Pola Asuh Orang Tua yang sesuai dengan tuntunan Agama serta Penerapan Hukuman disekolah harus diterapkan untuk merubah Perilaku Siswa yang kurang baik menjadi Perilaku yang baik atau terpuji. Oleh karena itu pada penelitian ini memfokuskan pada Penerapan Hukuman serta Pola Asuh Orang Tua sehingga dapat mempengaruhi Perilaku Siswa. Dalam hal ini dibuktikan dengan hasil penelitian yang menyebutkan bahwa :

Penelitian ini bertujuan untuk mengetahui dan menguji data-data empirik terkait dengan Penerapan Hukuman dan Pola Asuh Orang Tua terhadap Perilaku Siswa secara terpisah maupun simultan. Dalam penelitian ini penulis menggunaka metode survei, dengan teknik korelasional dan analisis regresi sederhana dan ganda. Sampel penelitian ini sebanyak 116 responden atau menggunakan seluruh jumlah siswa MAN 10 Jakarta. Pada tehnik pengumpulan data menggunakan angket, observasi, dan studio dokumenter. Tehnik analisa data yang digunakan model analisis Deskriptif, Koefisien korelasi, analisis regresi sederhana dan regresi ganda. Jenis analisis yang digunakan adalah analisa korelasi dan regresi ganda yang dijabarkan secara deskriptif. Hasil penelitan ini menunjukkan bahwa :

Pertama, Terdapat pengaruh positif dan signifikan Penerapan Hukuman terhadap Perilaku Siswa di MAN 10 Jakarta. Hal ini dibuktikan dengan hasil 
nilai koefisien korelasi sebesar 0,187 (korelasi rendah) dan koefisien determinasi $\mathrm{R}^{2}$ sebesar 0,035 artinya besarnya pengaruh sebesar 3,5\%. Regresi sederhana menunjukkan persamaan regresi $\hat{Y}=116,096+0,161 X_{1}$, yang berarti bahwa setiap peningkatan satu unit Penerapan Hukuman akan mempengaruhi peningkatan skor Perilaku Siswa 0,161 poin.

Kedua, Terdapat pengaruh positif dan signifikan Pola Asuh Orang tua terhadap Perilaku Siswa di MAN 10 Jakarta. Hal ini dibuktikan dengan hasil nilai koefisien korelasi sebesar 0,887 (korelasi sangat kuat) dan koefisien determinasi $\mathrm{R}^{2}$ sebesar 0,787 artinya besarnya pengaruh $78,7 \%$. Regresi sederhana, menunjukkan persamaan regresi $\hat{Y}=43,176+0,686 X_{2}$ yang berarti bahwa setiap peningkatan satu unit Pola Asuh Orang Tua akan mem-pengaruhi peningkatan skor Perilaku Siswa sebesar 0,686 poin.

Ketiga, Terdapat pengaruh positif dan signifikan Penerapan Hukuman dan Pola Asuh Orang Tua secara bersama-sama terhadap Perilaku Siswa di MAN 10 Jakarta. Hal ini dibuktikan nilai koefisien korelasi ganda $\mathrm{R}^{2}$ sebesar 0,787 artinya besarnya pengaruh sebesar 78,7\% dan regresi ganda yang dilakukan secara bersama-sama, menunjukkan persamaan regresi $\hat{Y}=22,145+$ $0,150 X_{1}+0,685 X_{2}$ yang berarti bahwa setiap peningkatan satu unit skor Penerapan Hukuman dan Pola Asuh Orang Tua akan mempengaruhi peningkatan skor Perilaku Siswa sebesar 0,835 poin. 


\section{DAFTAR PUSTAKA}

Amin Daten Indra Kusuma, Pengantar Ilmu Pendidikan, Surabaya: Usaha Nasiaonal, 1999

Ahmad Tafsir, Pendidikan Anak dalam Keluarga, Bandung: Remaja Rosdakarya, 1996

Chaotib Thoha, Kapita Selekta Pendidikan Islam, Yogyakarta: Pustaka Pelajar, 2003

Casmini, Emotional Parenting Dasar-dasar Pengasuhan Kecerdasan Emosi Anak, Yogyakarta: Pilar Media, 2007

Emile Durkheim, Pendidikan Moral: Suatu Studi teori dan aplikasi sosiologi pendidikan, terjemah oleh Lukas Ginting, Jakarta: Erlangga, 1990

J.B, Bigner, Parent Child Relation An Introduction To Parenting, New York Mac Millan Publishing Co, Mac Millan Publishing, 1779

Schohib, Pola Asuh Orang Tua Dalam Membantu Anak Mengembangkan Disiplin Diri, Jakarta: Rineka Cipta, 2001

Slameto, Belajar dan Faktor-Faktor yang Mempengaruhinya, Jakarta: Rineka Cipta, 1996

Sugiyono, Metode Penelitian Pendidikan Pendekatan Kuantitatif, Kualitatif, dan $R \mathcal{E} D$, hal. 117

Suharsimi Arikunto, Prosedur Penelitian Suatu Pendekatan Praktek, Jakarta: Rineka Cipta, 2002

S. Nasution, Sosiologi Pendidikan, Jakarta: Bumi Aksara, 1995 